\title{
The Effect Of Teaching Methodology On Accounting Students' Perceptions Of Traits Important To Success
}

\author{
Linda M. Nichols, The University of Tulsa, USA
}

\begin{abstract}
This study evolved from a previous study that examined the perceptions of the importance of specific traits to success in the accounting profession by both accounting professionals in the United States and internationally. That study found that the international subjects valued some soft skills, such as creativity, as being more important to success than did the subjects in the United States. Because of the importance of soft skills to success in the accounting profession worldwide, I sought to determine if teaching methodology in the accounting classroom in the United States could affect the perceptions of students regarding the importance of traits to success in the accounting profession. Three particular new methodologies were added to the accounting courses in which the study was run; a team debate, a writing assignment justifying an impairment decision in an unclear situation, and a team presentation in which creativity was a very significant percentage of the final grade. The results revealed that the traits of persuasiveness, good oral communication skills, good marketing skills, and creativity were ranked significantly more important by the student subjects at the end of the semester term than they were at the beginning of the semester term. Based on these results, accounting educators need to experiment to find methodologies that relate to their specific accounting courses that will help students realize the importance of soft skills for professional success in accounting.
\end{abstract}

Keywords: Teaching Methodology; Soft Skills; Teaching Accounting

\section{INTRODUCTION}

C n a previous study, I examined the perceptions of traits important to success in the accounting profession by accounting professionals, both in the United States (U.S.) as well as internationally. In that study I found that the international subjects valued some soft skills more than did accountants in the U.S. as being important to success in the accounting profession (Nichols, 2016). That finding seemed logical because international financial reporting standards (IFRS) are principles-based and require more judgment in application on the part of the accountant than do the rules-based standards found in the U.S. (IASB, 1973-; FASB 1973-). This study expands on those findings by incorporating different activities in the accounting classroom in the U.S. to determine if they would influence U.S. accounting students regarding their ranking of traits to the importance of success in the accounting profession.

\section{THE PREVIOUS STUDY}

In the above mentioned previous study, I surveyed energy industry accountants from the U.S, Budapest, the United Kingdom, and Russia. The surveys were administered on-site at CPE training seminars that I conducted. The instrument asked the subjects to rank twenty traits or characteristics according to their importance to being successful in the accounting profession. The traits and characteristics were:

- Is persuasive

- Strictly adheres to rules

- Adapts easily to new circumstances

- Is creative

- Is receptive to new ideas

Copyright by author(s); $\underline{\mathrm{CC}-\mathrm{BY}}$
The Clute Institute 
- Has strong leadership skills

- Is detail oriented

- Has good written communication skills

- Has a high level of integrity

- Has good oral communication skills

- Dresses conservatively and professionally

- Has good technical knowledge of accounting

- Has good computer skills

- Has good research skills

- Is good with spreadsheet programs such as EXCEL

- Has good analytical skills

- Works well in teams

- Is dedicated to continuous learning

- Has good critical thinking skills

- Has good marketing skills

The research design for the study was a $2 \times 4 \times 2$ factorial with the three factors being (1) respondent location, (2) years of full-time work experience, and (3) public accounting background (Tabachnick \& Fidell, 2010). The respondent location variable had two levels, either U.S. or international, the work experience variable had four levels with the lowest being less than 10 years and the highest being over 10 years, and the public accounting variable had two levels with the accountant either having worked in public accounting or not. No interaction effects were found between the three factors and no significant differences were found based on years of experience or whether the subject had worked in public accounting. However, seven of the traits revealed significant differences at the .05 significance level based on whether the respondent was from the U.S. or an international location. Those seven factors were:

(1) Adapts easily to new circumstances - International subjects ranked this as more important than U.S. subjects did.

(2) Is creative - International subjects ranked this as more important than U.S. subjects did.

(3) Has strong leadership skills - The U.S. subjects ranked this factor as more important than the international subjects did.

(4) Has a high level of integrity - The U.S. subjects ranked this factor as more important than the international subjects did.

(5) Has good oral communication skills - The U.S. subjects ranked this factor as more important than the international subjects did.

(6) Is dedicated to continuous learning - International subjects ranked this as more important than U.S. subjects did.

(7) Has good marketing skills - International subjects ranked this as more important than U.S. subjects did (Nichols, 2016).

In addition to the above factors that were significant at the .05 level, the following three additional factors reflected marginal significance between U.S. and international subjects at the .10 level:

(1) Is receptive to new ideas - International subjects ranked this as more important than U.S. subjects did.

(2) Is detail oriented - The U.S. subjects ranked this factor as more important than the international subjects did.

(3) Has good written communication skills - The U.S. subjects ranked this factor as more important than the international subjects did (Nichols 2016).

Overall, this study provided evidence that accountants in countries using IFRS which requires more judgment to apply, view traits such as creativity, adaptability, and being receptive to new ideas as more important than their U.S. counterparts. 


\section{THE CURRENT STUDY}

After performing the above study, I considered how our teaching methodology in the accounting classroom in the U.S. could in turn influence our students regarding the traits they believe to be most important to having a successful career in accounting. Could we do more in our classrooms to convey the importance of traits such as creativity and adaptability to our students? We certainly believe that they are important traits for success in the profession. To test the possibility, I added three additional dimensions to my energy accounting courses taught at a mid-western university in the U.S. The three additional dimensions were:

(1) A classroom debate - Near the beginning of the semester (before the U.S. presidential election), students were assigned to teams. The teams were asked to debate which presidential candidate would have a more positive effect on the energy industry. The teams were not able to choose which candidate they wanted to represent but were assigned candidates. The purpose of this exercise was to get the students thinking outside the box of a normal accounting course. The course addressed the energy industry specifically, and which candidate won the election could dramatically affect the industry and its future direction.

(2) An individual writing assignment defending an impairment decision - In the energy industry as in many industries, the decision of whether or not to impair asset groups is not always straight forward. It can be even more difficult for oil and gas companies, due to volatility of prices and some level of uncertainty regarding the amount of reserves in the ground. The students were presented with a situation that was not straight forward and were assigned to write a memo to the auditor defending their stance on either recognizing or not recognizing an impairment. The purpose of this exercise was to emphasize the importance of judgment in accounting and having students practice backing up their judgment call in writing.

(3) Increased level of importance of creativity in team presentations - Student teams were assigned to record a video presentation on a current industry topic. While this assignment had been given in past semesters, the big change in the rubric for this semester was that creativity was now worth 25 percent of the total grade whereas creativity had not been included as a separate category in the rubric in previous semesters. The purpose of this assignment was to get students to think about how to creatively express their ideas, and not just write and recite facts on PowerPoint slides.

The students in the courses were asked to rank the same twenty traits as appeared on the instrument from the previous study (Nichols, 2016) on both the first day of class for the semester and the last day of class for the semester. The students ranked each of the characteristics or traits based on their importance of being successful in the accounting profession using the following five-point scale:

1 Not at all important

2 Low level of importance

3 Somewhat important

4 Very important

5 Most important

The research design is a $2 \times 4 \times 6$ factorial (Tabachnick \& Fidell, 2010). The three factors are (1) point of time in semester, (2) classification in college, and (3) major field of study in college. The point of time in semester factor has two levels, either the beginning or end of the semester. The classification in college factor had four levels; sophomore, junior, senior, or graduate student. The major field of study factor had six levels; accounting, energy management, other business undergraduate major, other business graduate major, and other. A separate model was run for each trait or characteristic. The average rankings for each factor both at the beginning and end of the semester are presented in Table 1. It can be noted from Table 1 that the three factors that ranked the highest at both the beginning and end of the semester were (1) a high level of integrity, (2) good technical knowledge of accounting, and (3) is detail oriented. This reflects both the technical nature of accounting and its place in society as a trusted profession of integrity. 
Table 1.

\begin{tabular}{l|c|c}
\hline \multicolumn{1}{c}{ Trait } & Beginning of Semester & End of semester \\
\hline Is persuasive & 2.574 & 3.000 \\
\hline Strictly adheres to rules & 4.462 & 4.452 \\
\hline Adapts easily to new circumstances & 3.903 & 4.000 \\
\hline Is creative & 2.292 & 2.710 \\
\hline Is receptive to new ideas & 3.419 & 3.577 \\
\hline Has strong leadership skills & 3.500 & 3.581 \\
\hline Is detail oriented & 4.692 & 4.613 \\
\hline Has good written communication skills & 4.077 & 4.097 \\
\hline Has a high level of integrity & 4.645 & 4.808 \\
\hline Has good oral communication skills & 3.548 & 3.923 \\
\hline Dresses conservatively and professionally & 3.269 & 3.232 \\
\hline Has good technical knowledge of accounting & 4.654 & 4.581 \\
\hline Has good computer skills & 4.385 & 4.165 \\
\hline Has good research skills & 3.581 & 3.769 \\
\hline Is good with spreadsheet programs such as EXCEL & 4.346 & 4.355 \\
\hline Has good analytical skills & 4.423 & 4.419 \\
\hline Works well in teams & 3.731 & 3.742 \\
\hline Is dedicated to continuous learning & 3.923 & 4.065 \\
\hline Has good critical thinking skills & 4.192 & 4.258 \\
\hline Has good marketing skills & 2.387 & 2.807 \\
\hline
\end{tabular}

Based on a significance level of .05, four of the trait rankings reflected significant differences between the beginning and end of the semester. There were no significant differences found based on student classification or major field of study. No interaction effects were present for any of the traits. The four traits with significant differences between the beginning and end of the semester at the .05 level are:

(1) Is persuasive

This factor ranked as more important at the end of the semester than at the beginning of the semester, with a ranking of 2.574 at the beginning of the semester and a ranking of 3.000 at the end of the semester. While the end of the semester average is still not very high, it did increase by a significant amount from the beginning of the semester. Both the in-class team debate assignment as well as the individual written assignment justifying an impairment decision helped the students understand the importance of persuasiveness.

(2) Has good oral communication skills

This factor ranked as more important at the end of the semester than at the beginning of the semester, with a ranking of 3.548 at the beginning of the semester and a ranking of 3.923 at the end of the semester. Both the team debate assignment as well as the team presentation helped the students understand more fully the importance of good oral communication skills to success in the profession.

(3) Has good marketing skills

This factor ranked as more important at the end of the semester than at the beginning of the semester, with a ranking of 2.387 at the beginning of the semester and a ranking of 2.807 at the end of the semester. Both the team debate assignment as well as the individual written assignment justifying an impairment decision played a part in the increased ranking for marketing skills. While the ranking is still not high overall, the increase was significant. Writing a justification for an impairment decision may have been considered by students as a type of marketing of the student's professional judgment on the matter.

(4) Is creative

This factor ranked as more important at the end of the semester than at the beginning of the semester, with a ranking of 2.292 at the beginning of the semester and a ranking of 2.710 at the end of the semester. The importance placed on creativity in the team presentations influenced this increase. However, students also had to be creative in considering how to present the debate and in writing the impairment decision justification, although creativity was not a specific part of the rubric for those assignments. 
While the ranking at the end of the semester was still not high, the increased perception of the importance of creativity to success in the accounting profession was significant.

In addition to the above factors with significant differences between beginning and end of semester rankings at the .05 significance level, the following factor showed a marginally significant difference between the beginning and end of semester rankings at the .10 level of significance:

(1) Has good computer skills

This factor ranked as more important at the beginning of the semester than at the end of the semester, with a ranking of 4.385 at the beginning of the semester and a ranking of 4.165 at the end of the semester. I did not anticipate this marginal difference. What I have learned from this marginal result is that I need to incorporate more computer-based assignments because of the importance of having good computer skills to success in the profession. Overall, however, the average ranking for this trait was high at both the beginning and end of the semester indicating that students do recognize computer skills as an important trait to professional success.

\section{CONCLUSION}

Accounting professionals in the U.S. do not view soft skills to be as important to success in the accounting profession as do accounting professionals in other countries that follow IFRS (Nichols, 2016). Soft skills include, among other traits, creativity, marketing, and adaptability. The principles-based nature of IFRS requires more judgment in application in comparison to the rules-based standards of the U.S. (IASB, 1973-). The principles-based versus rulesbased paradigm difference could account for the perception of soft skills as being more important to users of IFRs than to users of U.S. GAAP. However, accounting professionals in the U.S. must often exercise professional judgment regarding application of standards to specific situations and sets of circumstances and they must be able to effectively communicate the justification for their decisions. Teaching methodology and practices in the accounting classroom can affect students' perceptions of traits important to success in the accounting profession, as reflected in this study. It is important for accounting educators to experiment with different types of assignments and classroom activities that would relate to their specific course material in order to assess how both technical skills and relevant soft skills can be emphasized and applied to those specific courses. This, in turn, will help accounting students in the U.S. realize the importance of the development of their soft skills to their future professional success.

\section{AUTHOR BIOGRAPHY}

Linda Nichols currently serves as the Funai Chaired Professor in Energy and Accounting at The University of Tulsa. Linda is a CPA and earned a PhD in Accounting at Louisiana State University. Previously, she held the position of E\&Y Professor and Director of Accounting Programs at Texas Tech University. Linda is author of a BNA portfolio in Upstream Accounting.

Linda has received both the Texas Society of CPAs' Outstanding Accounting Educator Award, and the Outstanding Educator of the Year Award from the American Woman's Society of CPAs. She also served as the Fulbright Johannes-Kepler Distinguished Chair in International Business.

\section{REFERENCES}

Nichols, L. (2016). A study of the perceptions of traits important to success in the accounting profession by U.S. versus international accountants. International Journal of Business and Applied Social Science, February 2016, 51-56.

Financial Accounting Standards Board (1973-). Statements of Financial Accounting Standards, 1973-present, Norwalk, CT. International Accounting Standards Board (1973-). International Financial Reporting Standards, 1973-present, London, U.K.

Tabachnick, B. \& Fidell, L. (2010). Multivariate Analysis of Variance, University of Southern California. 


\section{NOTES}

